\title{
EXPERIMENTAL STUDY ON ENGINEERING EFFECT OF HOLLOW-BLOCK MOUND BREAKWATER
}

\author{
Wu Hualin ${ }^{1}$, Zhang Junyong ${ }^{2}$, Liu Gaofeng ${ }^{1}$
}

\begin{abstract}
Effects of estuary regulation engineering are related to structure type of its dykes, but it is difficult to study the effect of local complex structure with physical model directly. Taking N II C segment of the $2^{\text {nd }}$ phase project of Deep Water Channel at Yangtze Estuary as a case, the paper discussed the method of research on engineering effect of hollow block structure by combining flume experiment with physical model. The method makes it possible to research the effects on current and riverbed induced by complex local structure with large-scale physical model. By comparison of different schemes, it is derived that the scheme without $2600 \mathrm{~m}$-long training dike of NIIC segment do harm to the exit channel of North Passage, and there are little influence with the scheme of the height of $2600 \mathrm{~m}$-long training dike of NIIC segment debasing $1 \mathrm{~m}$ or the scheme of adopting hollow-block mound breakwater structure.
\end{abstract}

Key words: hollow-block mound breakwater, permeability, engineering effect, flume experiment, physical model

Waterproof and weakly water-permeable structure types such as caissons, rubble mound are widely used in estuary and coastal engineering. Two sorts of structures are popularly used in building seawall and designed training dike when the groundwork is of silt or soft clay: one is rubble slope mound on reinforced groundwork, including the rubble mound with artificial blocks; another is the pile structure (Xie, 1996). The regulation engineering in the project of Deep Water Channel at Yangtze Estuary are mainly formed by three parts: south training dike, north training dike and spur dike groups between them. The south training dike is $48.077 \mathrm{~km}$ long, and the north designed training dike is $49.200 \mathrm{~km}$ correspondingly. N II C segment, which lies in the upper north training dike with the length of $2.6 \mathrm{~km}$, is on the groundwork of in argillaceous soil. The under putty surface elevation of groundwork is approximately -7.6 -8.6m (the Woosung basic plane). On this groundwork, with the failure field test of inserting big prestressed reinforcement concrete cylinder structure, more than 20 application schemes were proposed by many domestic designing departments. Among the 20 schemes including replacement of artificial block body mask in the slope mound or artificial block body mask packed in bags granulated substance core of bank mound breakwater on the sand groundwork; the in-depth cement mixes up (CDM) and in semicircle caisson mix dike the ground; stand erect dike with sunk reinforced concrete big cylinder and stand erect the dike with sunk steel cylinder, etc.. By comparing all the 20 schemes, the new developed hollow block mound breakwater (Xie et al. 2004) was adopted for the advantages of genius design, less weight, convenient construction, reasonable construction cost, well stability, and small risk.

Since this new structure is being used in the domestic river and sea engineering for the first time, some key problems, which may determine whether or not a scheme will be adopted, need to be solved in laboratory in advance. The key questions include: character of water permeability, the influence of different hollow block structure and its place form to the character of water-permeable, whether the effect of regulation project will be influenced by water percolation, the influence of the water

\footnotetext{
${ }^{1}$ Shanghai Estuarine and Coastal Science Research Center, Ministry of Transport, Xinsheng Road 1045\#, Pudong District, Shanghai,201201, P. R. China

${ }^{2}$ Yangtze Estuary Waterway Administration Bureau, Ministry of Transport, Weihai Road 48\#, Shanghai,200003, P. R. China
} 
percolation to the basic functions of training dike ----"conducting current, blocking the sand, reducing the silt", etc.. Flume and physical model is a valid way widely used in the research of estuary and coastal engineering problems (Huang, 1995; Yang, 2001; Han et al. 2002). But still few were performed on the water permeability of mound structures. Based on the projects in the $2^{\text {nd }}$ phase project of Deep Water Channel at Yangtze Estuary, a normal model of flume experiment and a big metamorphosis physical model were creatively combined in this paper to research the former problems. It is basic aiming to provide a scientific basis for project decision-making and instruction opinion for further design.

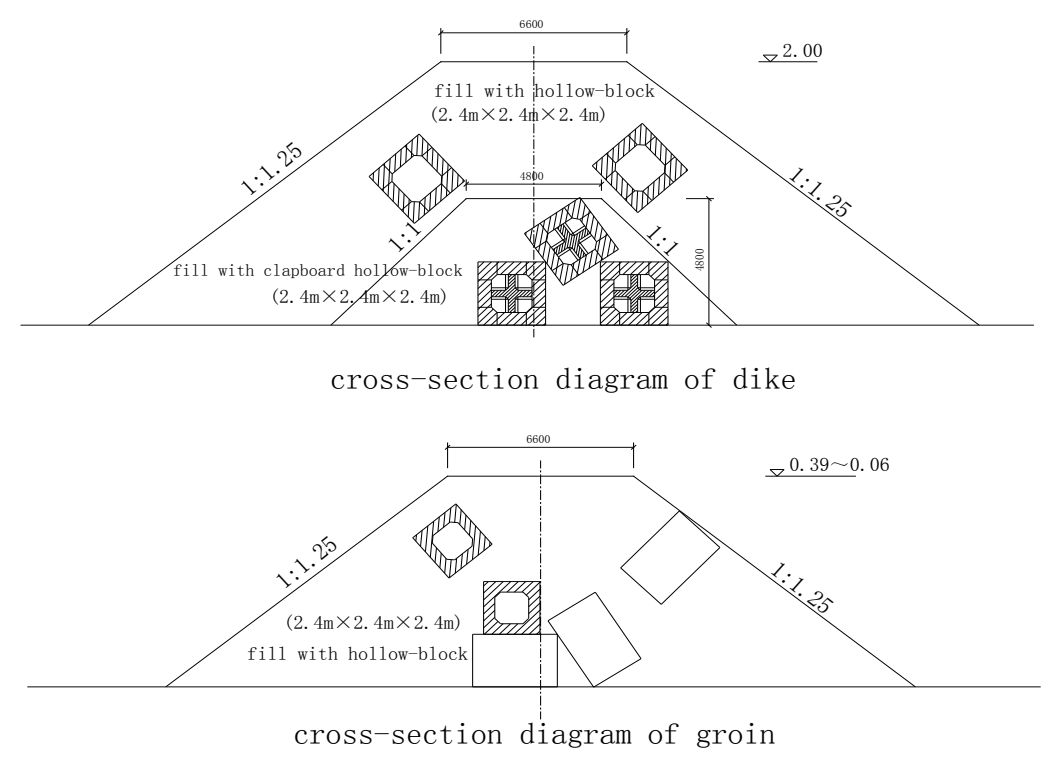

Fig.1 designed training dike and groin structure in NIIC segment

\section{Research method}

According to the design document, the NIIC designed training dike was constructed with porous hollow blocks of $2.4 \mathrm{~m} \times 2.4 \mathrm{~m} \times 2.4 \mathrm{~m}$.Inside the dike was also constructed with the same block constitutes with partition board (Fig. 1a). Spur dikes in N II C segment were constructed by hollow block constitutes of $2 \mathrm{~m} \times 2 \mathrm{~m} \times 3 \mathrm{~m}$ (Fig. $1 \mathrm{~b})$.

For the difficulty in modeling the small-scale structure of hollow block mound breakwater in distorted model, small scale undistorted model of flume experiment was adopted to replace it. With this method, accurate simulation in partial structure was possible in the huge physical model of Yangtze estuary. So the influence of different structure types of mounds to the total effect of regulation engineering can be researched. On the other hand the penetrability character of different structure pattern may be researched by flume experiments as well.

The detail was: use the 1:20 normal flume model to study the permeability of prototype structure, 
and then find the similar simplified structure which can be used in the big model of Yangtze estuary, so as to study the influence of project structure to the effect of regulation engineering.

\section{Flume experiment}

\subsection{Model design}

The experiments were performed in a flume with changeable slope and wave flow, the flume was $35 \mathrm{~m}$ long, $0.5 \mathrm{~m}$ wide, and $0.7 \mathrm{~m}$ deep, equipped with electromagnetic current meter, the three dimensional ADV current meter, lathe flow-velocity meter, water level meter and so on. Normal model with the ratio of 1:20 was designed based on the physical body of flume. The simulation between the model and the prototype may be guaranteed while the geometry and material was similar. The model was mainly designed according to the law of similitude in flow kinematical conditions. The related scales relations may be calculated by the two-dimensional non-steady flow equation of motion and the equation of continuity.

2.1.1 Normal model with scale relation of 1:20

$$
\begin{aligned}
& \lambda_{L}=\lambda_{h}=20 \\
& \lambda_{Q}=\lambda_{L}^{5 / 2}=1788.85
\end{aligned}
$$

Here $\mathrm{L}$ means length, $\mathrm{h}$ means water depth, $\mathrm{Q}$ is flow discharge, $\lambda$ is scale relation. When actual flow discharge is $Q_{M}\left(m^{3} / s\right)$, then prototype flow discharge of list wide $\left.q_{P}\left(m^{3} / s . m\right)\right)$ can be calculated as

$$
\begin{gathered}
B_{P}=B_{M} \cdot \lambda_{L} \\
Q_{P}=Q_{M} \cdot \lambda_{Q} \\
q_{P}=\frac{Q_{P}}{B_{P}}=\frac{Q_{M} \cdot \lambda_{Q}}{B_{M} \cdot \lambda_{L}}=178.885 Q_{M}
\end{gathered}
$$

2.1.2 Model with scale relation: vertical 1:125, plane 1:1000

$$
\begin{aligned}
& \lambda_{L}=1000, \lambda_{H}=125 \\
& \lambda_{Q}=\lambda_{L} \lambda_{h}^{3 / 2}=1397542.49
\end{aligned}
$$

When actual flow discharge is $Q_{M}\left(m^{3} / s\right)$, then prototype flow discharge of list wide $\left.q_{P}\left(m^{3} / s . m\right)\right)$ can be calculated as

$$
\begin{aligned}
& B_{P}=B_{M} \cdot \lambda_{L}=0.5 \times 1000=500 m \\
& Q_{P}=Q_{M} \cdot \lambda_{Q}=1397542.49 Q_{M} \\
& q_{P}=\frac{Q_{P}}{B_{P}}=2795.085 Q_{M}
\end{aligned}
$$

2.2 Results 
The water permeability of training dike and groins with hollow block mound structure was studied by flume experiments. Hollow blocks were made according to the scale relation of 1:20. Training dike and spur dike with the structure of rubble mound were widely used in the first phase project of Deep Water Channel at Yangtze Estuary, and proved to be little permeable by field data.

For the proper appraisal of water permeability of hollow block structure, rubble mound should be modeled as a foundation for compare. Inside the mounds used in the project of Deep Water Channel at Yangtze Estuary was mainly rubble stone weighed $10 \sim 100 \mathrm{~kg}$, which should be stones $1.25 \sim 12.5 \mathrm{~g}$ weight in the experiment based on the ratio rule. But actually we took $0.3 \sim 17 \mathrm{~g}$ crushed stone instead. The porosity gauged in laboratory was $47.2 \%$. The body of $\mathrm{r}$ rubble mound was actually constructed with rubble stones $300 \sim 400 \mathrm{~kg}$ in weight, but corresponding stone calculated in model may be $37.5 \sim$ $50 \mathrm{~g}$ in weight, finally we took $40 \sim 50 \mathrm{~g}$ crushed stone for simulation with the porosity gauged in laboratory was $48.7 \%$.

The mound structural model was placed in the middle of the flume, and flow will penetrate the mound while a water level difference exists. Maintain certain discharge constantly and after a while, a stable water level difference can be gauged. The flume discharge was gauged by the electromagnetic flow meter and verified by lathe flow-velocity meter. Obviously, the bigger the flow discharge through the mound was, the greater difference of water level between the upper stream and downstream was. Relational curve between them reflected the water percolation characteristic of certain structure.

Seen from fig.2, the water percolation degree of designed training dike structure was obviously more serious than that of designed spur dike. When the water level difference was $60 \mathrm{~cm}$, the flow discharge of list wide went through the rubble mound was only $1.2 \mathrm{~m}^{2} / \mathrm{s}$ and the corresponding discharge through the designed spur dike was $2.9 \mathrm{~m}^{2} / \mathrm{s}$. Compare with rubble mound the water percolation degree in designed training dike and the designed spur dike were much bigger. When the water level difference was $60 \mathrm{~cm}$, the flow discharge of list wide went through the rubble mound was only $1.2 \mathrm{~m}^{2} / \mathrm{s}$. The structure of designed training dike had a list wide discharge 3.5 times to that of rubble mound, and the design spur dike structure was 2.4 times to that. In addition, influence of different construction methods of hollow block to water percolation was also studied(Wu, 2005 ).

On this foundation, according to the request of Yangtze estuary model, we studied the simplified structures of hollow block training dike and spur dike by flume experiments. By changing water percolation in the simplified training dike and spur dike with a vertical scale of 1:125 and plane scale of 1:1000, we acquired proper water percolation relation which coincided the curve of water level difference $\sim$ water percolation discharge between prototype and model. The comparison can be seen in Fig. 3 and Fig. 4. In a whole, the similarity proved to be fine. The experimental achievement may be supplied in the Yangtze estuary model in studying the influence of different water percolation structure to the effect of regulation engineering. 


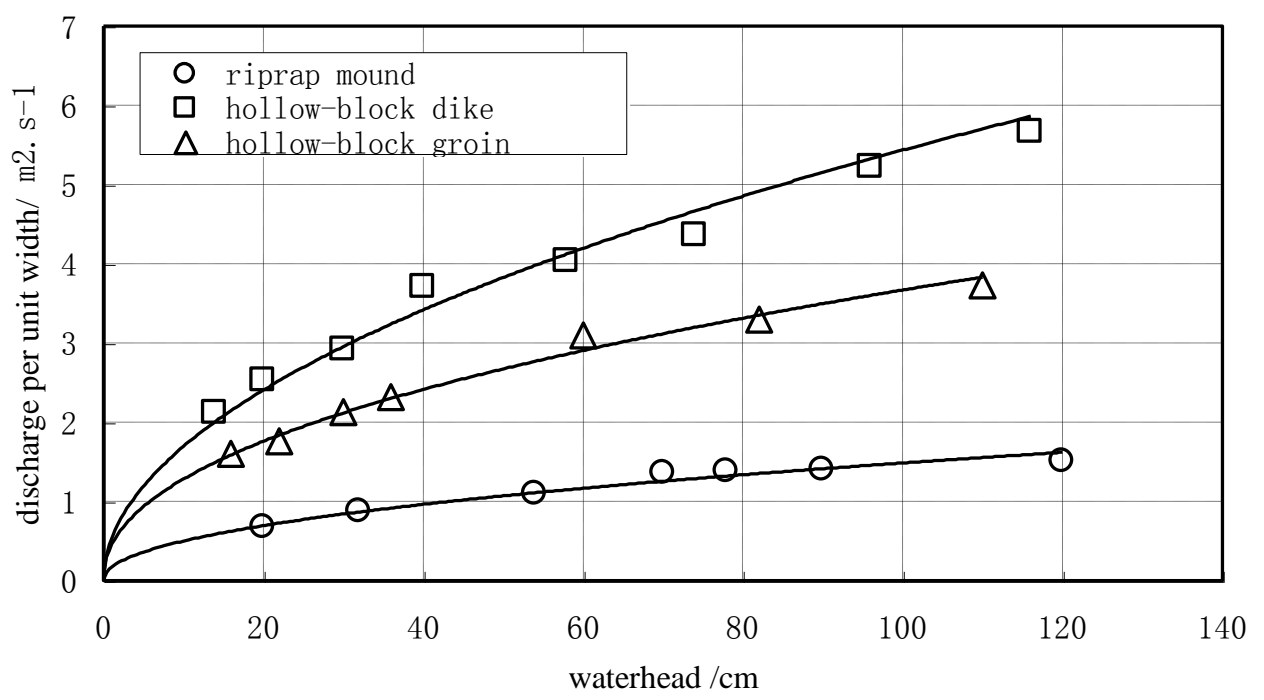

Fig.2 Permeability curves of the designed training dike and groin structure of NIIC segment

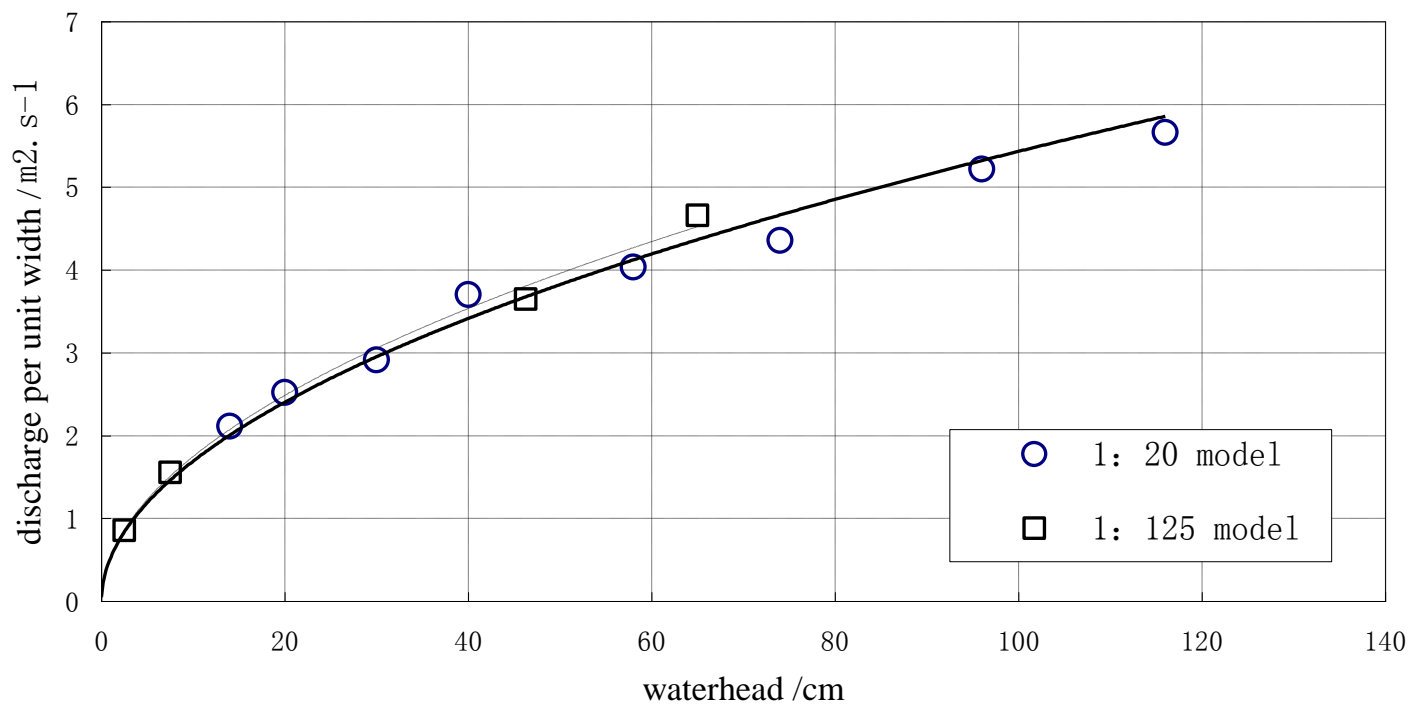

Fig.3 Permeability curves of the different scale designed training dike 


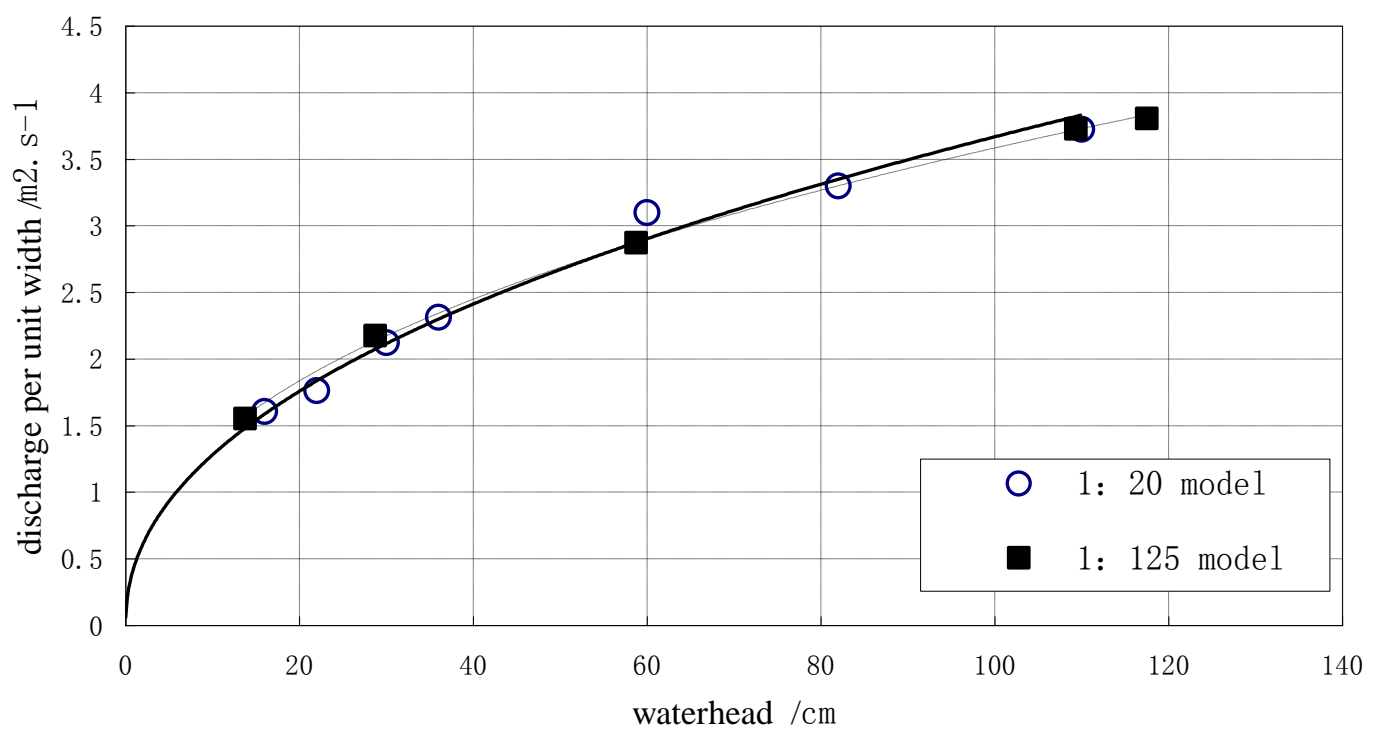

Fig.4 Permeability curves of the different scale designed groin

\section{Physical model experiments}

\subsection{Introduce of model}

In order to solve the many technical problems in construction of deep water channel in Yangtze estuary, the Ministry of Communications investigated to construct the Yangtze estuary integrity physical model in Shanghai in 1998.The model is huge with the plane scale relation was 1,000 and vertical scale relation was 125 , changing rate was 8 . The peak of tidal current in Yangtze estuary is nearby Jiangyin, Jiangsu Province. The model terrain is upper to Ligang, 10km upstream Jiangyin gauging station. Considering the interaction of branches downstream Xuliujing, the north boundary of the model was in Subeizui, and the south boundary was in Nanhuizui. Open sea boundary was approximate $40 \mathrm{~m}$ isobaths outside the mouth of northern Branch, $35 \mathrm{~m}$ isobaths outside North Channel, $30 \mathrm{~m}$ isobaths outside North Passage and $25 \mathrm{~m}$ isobaths outside South Passage. Upstream the boundary is located in Datong, 400km apart from Jiangyin in Anhui Province. For the similar of tidal wave, Datong and Ligang was connected with a distorted channel. The layout of model can be seen in Fig. 5. 


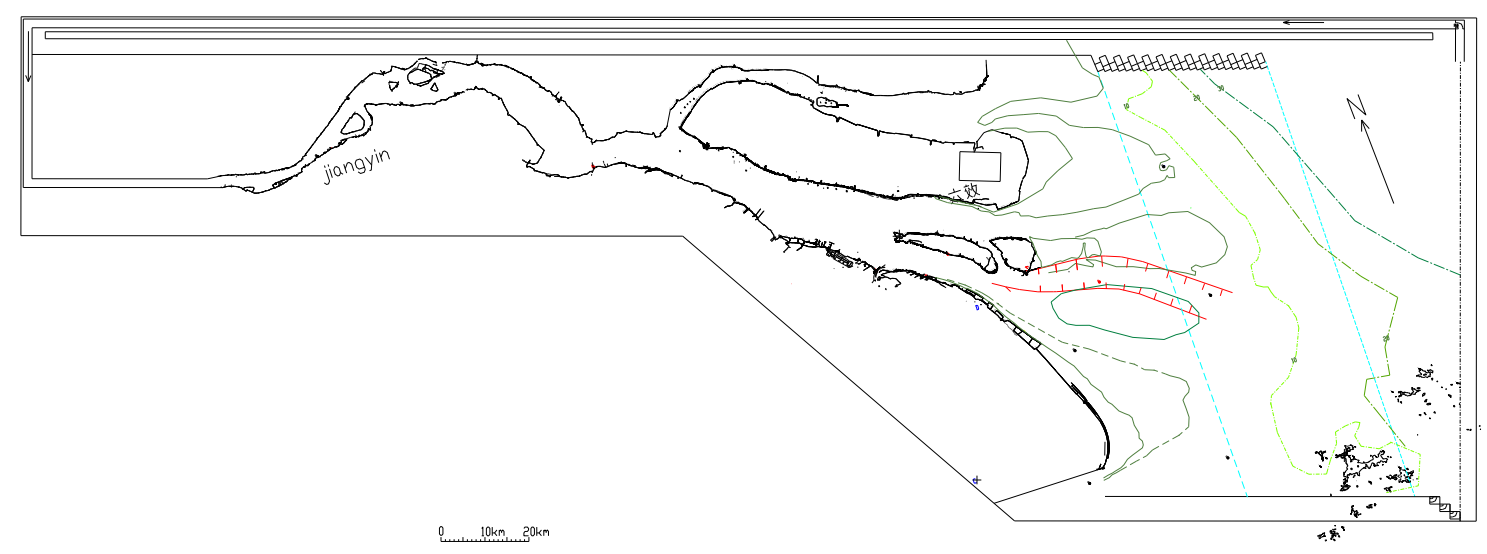

Fig.5 Sketch of Changjiang estuary model

The model was designed according to the laws of geometry similar, gravity similar, resistance similar, tidal current inertia similar, silt starts, bed load discharge similar, erosion and deposition time similar, settlement similar and so on. By compare, special handled model sediment was adopted to be the model sand to simulate bed load movement in the North Channel in Changjiang Estuary. The median diameter of model sediment was $0.15 \mathrm{~mm}$ with the bulk specific gravity is $1.12 \mathrm{t} / \mathrm{m}^{3}$; the dried bulk specific gravity was $0.6 \mathrm{t} / \mathrm{m}^{3}$. Scale relations in the model were in Table 1 .

Table 1 Model scale relations

\begin{tabular}{|c|c|c|c|c|}
\hline category & Name of ratio & symbol & Calculated value & Used value \\
\hline \multirow{2}{*}{$\begin{array}{l}\text { geometry } \\
\text { similarity }\end{array}$} & Plane length & $\lambda_{L}$ & 1000 & 1000 \\
\hline & Vertical height & $\lambda_{H}$ & 125 & 125 \\
\hline \multirow{5}{*}{$\begin{array}{c}\text { flow } \\
\text { similarity }\end{array}$} & velocity of flow & $\lambda_{u}$ & 11.18 & 11.18 \\
\hline & Flow time & $\lambda_{t}$ & 89.44 & 89.44 \\
\hline & Flow flux & $\lambda_{q}$ & 1397500 & 1397500 \\
\hline & Chezy coefficient & $\lambda_{c}$ & 2.83 & 2.83 \\
\hline & Maning's coefficient & $\lambda_{n}$ & 0.79 & 0.79 \\
\hline \multirow{7}{*}{$\begin{array}{l}\text { bed load } \\
\text { transport } \\
\text { similarity }\end{array}$} & specific gravity & $\lambda_{\gamma_{S}}$ & 2.366 & 2.366 \\
\hline & diameter of particles & $\lambda_{d}$ & 0.27 & 0.27 \\
\hline & threshold velocity & $\lambda_{U_{c}}$ & 11.18 & $10.48 \sim 12.9$ \\
\hline & Falling velocity & $\lambda_{\omega}$ & 1.4 & 0.97 \\
\hline & Dry volume-weight & $\lambda_{\gamma_{0}}$ & 2.0 & 2.0 \\
\hline & $\begin{array}{l}\text { Rate of sediment } \\
\text { transporting per width }\end{array}$ & $\lambda_{q_{s b}}$ & 346.5 & 356 \\
\hline & $\begin{array}{ll}\text { Erosion } & \text { and } \\
\text { deposition time } & \end{array}$ & $\lambda_{t 1}$ & 721.5 & 702 \\
\hline
\end{tabular}




\subsection{Model confirmation}

Model tide level was confirmed by flood tide process in 1998. As shown in Fig.5, the stations include Niupitan, Middle of North Channel, Hengsha, Changxing,Waigaoqiao, Wu Songkou, Baozhen, Nanmen port, Xuliujin and Jiangyin. Reciprocation flow inside the mouth was confirmed by field data of actual flood tide at the same time. In total sixteen points were distributed to measure flow velocity both in South Gang, North Gang, South Channel and North Channel. Because of Coriolis force, the fluid state in lower and mouth of North Channel presents the characteristic of revolves flows. For lack of field data, the field data of cross-section 5\# in 1997 and in DS1 and DS2 in 2000 were adopted on the confirmation. The experimental data indicated that the model tide level process line and flow distribution coincide with the prototype well. Reproduction of riverbed change in Yangtze estuary deep water route caused by the first phase project in 1999.2 2002.2 was carried out in a changeable riverbed model. Compare with the prototype, the model had a rough similar terrain both in area of erosion and deposition and the quantity in erosion and deposition(Wu, et al. 2003; Wu, et al. 2005) .

\subsection{Experimental schemes}

3.3.1 Consult experiment of the construction length of N II C segment in designed training dike

Case 0 , the background case, the determined planes scheme of arrangement in $2^{\text {nd }}$ phase project of Deep Water Channel at Yangtze Estuary. NIIC section was $2600 \mathrm{~m}$ long, the elevation of designed training dike is $+2.0 \mathrm{~m}$ (the Woosung basic plane, similarly hereinafter), with water-proof structure.

Case 1, N II C segment designed training dike does not construct, means the $2600 \mathrm{~m}$ long designed training dike does not exist;

Case2, Half of the N II C segment was constructed , means the 1300m long designed training dike does not construct.

\subsubsection{Consult experiments of the elevation of N II C segment designed training dike}

Case 3, the elevation of N II C segment designed training dike was -2.0m;

Case 4, the elevation of N II C segment designed training dike was $\pm 0 \mathrm{~m}$;

Case 5, the elevation of N II C segment designed training dike was +1.0m.

\subsubsection{Experiments on N II C segment with water percolation structure}

Case6, N II C segment was $2600 \mathrm{~m}$ long and $+2.0 \mathrm{~m}$ in elevation, constructed with $2.4 \times 2.4 \times 2.4 \mathrm{~m}$ hollow blocks. $2 \times 2 \times 3 \mathrm{~m}$ hollow block structure was adopted in the $100 \mathrm{~m}$ spur dike in segment $\mathrm{N} 6$, $950 \mathrm{~m}$ long spur dike in segment $\mathrm{N} 8$, and 800m long spur dike in segment N10 .

The water percolation designed training dike and spur dike were simulated by the equivalent simplified structures studied by flume experiments in preceding text.

\subsection{Results analysis}

Flow velocity, flow direction and the terrain near the project were gauged in experiments. The layout of cross section of flow velocity gauging can be seen in Figure 6. 


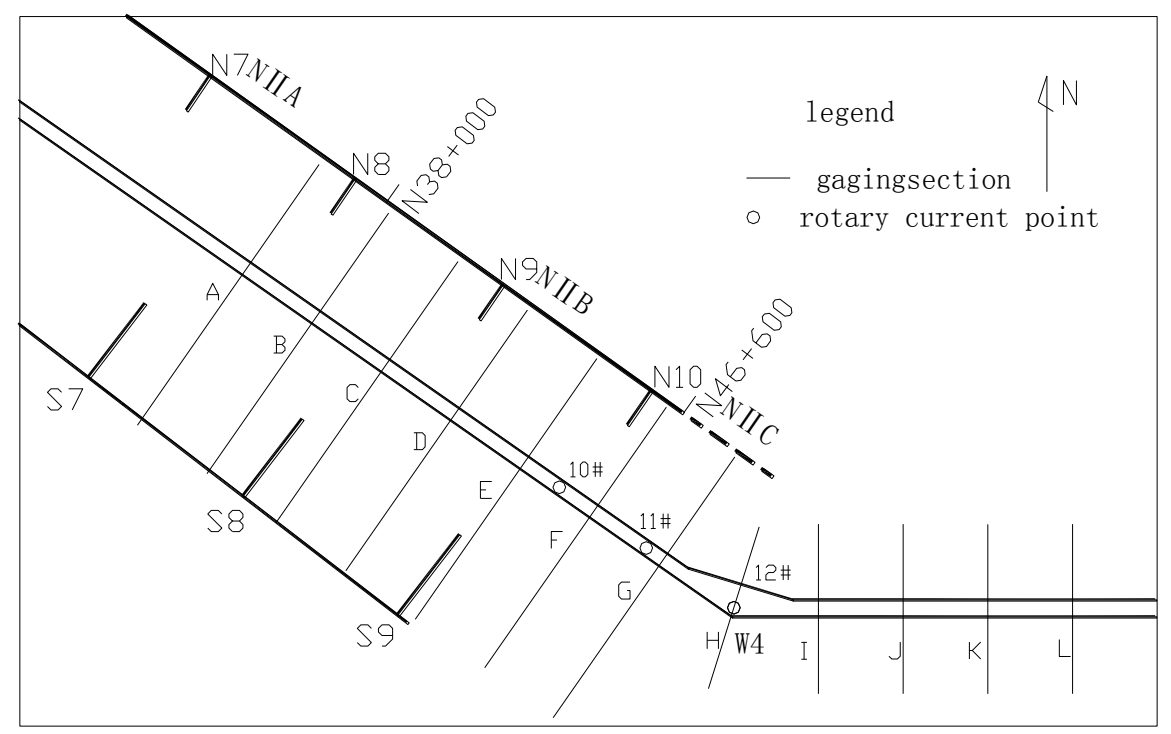

Fig.6 Flow velocity survey points in model

\subsubsection{Influence to flow velocity in sea-route}

Flow velocity data in channel can be seen in Table 2 and Table 3.

Table 2 Ebb velocities in the channel $(\mathrm{m} / \mathrm{s})$

\begin{tabular}{|c|c|c|c|c|c|c|c|c|c|c|c|c|c|}
\hline \multirow{2}{*}{$\begin{array}{l}\text { Section } \\
\text { number }\end{array}$} & \multirow{2}{*}{\begin{tabular}{|c|}
$\begin{array}{c}\text { Backgro } \\
\text { und }\end{array}$ \\
velocity
\end{tabular}} & \multicolumn{2}{|c|}{$\begin{array}{l}\text { Decrease } \\
2600 \mathrm{~m}\end{array}$} & \multicolumn{2}{|c|}{$\begin{array}{c}\text { Decrease } \\
1300 \mathrm{~m}\end{array}$} & \multicolumn{2}{|c|}{$\begin{array}{c}\text { Dike elevation } \\
\qquad-2 m\end{array}$} & \multicolumn{2}{|c|}{$\begin{array}{c}\text { Dike elevation } \\
0 \mathrm{~m}\end{array}$} & \multicolumn{2}{|c|}{$\begin{array}{c}\text { Dike elevation } \\
\qquad 1 \mathrm{~m}\end{array}$} & \multicolumn{2}{|c|}{ Permeable dike } \\
\hline & & velocity & $\Delta V$ & velocity & $\Delta V$ & velocity & $\Delta V$ & velocity & $\Delta V$ & velocity & $\Delta V$ & velocity & $\Delta V$ \\
\hline A & 2.05 & 1.98 & -0.06 & 2.03 & -0.02 & 2.00 & -0.04 & 2.07 & 0.02 & 2.09 & 0.04 & 2.07 & 0.02 \\
\hline B & 2.07 & 2.10 & 0.03 & 2.05 & -0.02 & 2.01 & -0.06 & 2.10 & 0.02 & 2.07 & -0.01 & 2.07 & -0.01 \\
\hline C & 2.09 & 2.04 & -0.05 & 2.04 & -0.05 & 2.11 & 0.02 & 2.09 & 0.00 & 2.08 & -0.01 & 2.08 & -0.02 \\
\hline D & 2.07 & 2.05 & -0.02 & 2.06 & -0.02 & 2.03 & -0.05 & 2.03 & -0.04 & 2.06 & -0.01 & 2.04 & -0.04 \\
\hline E & 2.00 & 1.93 & -0.07 & 1.99 & -0.01 & 1.95 & -0.04 & 1.93 & -0.06 & 2.01 & 0.01 & 2.01 & 0.01 \\
\hline $\mathrm{F}$ & 1.89 & 1.81 & -0.08 & 1.90 & 0.01 & 1.83 & -0.06 & 1.84 & -0.04 & 1.89 & 0.00 & 1.88 & -0.01 \\
\hline G & 1.77 & 1.69 & -0.08 & 1.70 & -0.07 & 1.70 & -0.07 & 1.71 & -0.06 & 1.75 & -0.02 & 1.73 & -0.04 \\
\hline $\mathrm{H}$ & 1.58 & 1.51 & -0.08 & 1.54 & -0.04 & 1.53 & -0.05 & 1.50 & -0.09 & 1.57 & -0.01 & 1.57 & -0.01 \\
\hline I & 1.43 & 1.35 & -0.09 & 1.39 & -0.04 & 1.36 & -0.08 & 1.36 & -0.07 & 1.42 & -0.01 & 1.41 & -0.02 \\
\hline $\mathrm{J}$ & 1.29 & 1.16 & -0.12 & 1.18 & -0.10 & 1.20 & -0.09 & 1.23 & -0.06 & 1.26 & -0.03 & 1.27 & -0.02 \\
\hline K & 1.25 & 1.15 & -0.10 & 1.15 & -0.10 & 1.18 & -0.07 & 1.19 & -0.06 & 1.23 & -0.02 & 1.24 & -0.01 \\
\hline L & 1.15 & 1.02 & -0.13 & 1.05 & -0.10 & 1.07 & -0.07 & 1.09 & -0.05 & 1.12 & -0.02 & 1.15 & 0.00 \\
\hline average & & & -0.07 & & -0.05 & & -0.06 & & -0.04 & & -0.01 & & -0.01 \\
\hline
\end{tabular}


Table 3 Flood velocities in the channel $(\mathrm{m} / \mathrm{s})$

\begin{tabular}{|c|c|c|c|c|c|c|c|c|c|c|c|c|c|}
\hline \multirow{2}{*}{\begin{tabular}{|l} 
Section \\
number
\end{tabular}} & \multirow{2}{*}{$\begin{array}{c}\text { Backgro } \\
\text { und }\end{array}$} & \multicolumn{2}{|c|}{$\begin{array}{c}\text { Decrease } \\
2600 \mathrm{~m}\end{array}$} & \multicolumn{2}{|c|}{$\begin{array}{c}\text { Decrease } \\
1300 \mathrm{~m}\end{array}$} & \multicolumn{2}{|c|}{$\begin{array}{c}\text { Dike elevation } \\
-2 m\end{array}$} & \multicolumn{2}{|c|}{$\begin{array}{l}\text { Dike elevation } \\
\text { Om }\end{array}$} & \multicolumn{2}{|c|}{$\begin{array}{c}\text { Dike elevation } \\
1 \mathrm{~m}\end{array}$} & \multicolumn{2}{|c|}{ Permeable dike } \\
\hline & & velocity & $\Delta V$ & velocity & $\Delta V$ & velocity & $\Delta V$ & velocity & $\Delta V$ & velocity & $\Delta V$ & velocity & $\Delta V$ \\
\hline$A$ & 1.21 & 1.18 & -0.03 & 1.16 & -0.06 & 1.13 & -0.09 & 1.14 & -0.07 & 1.15 & -0.06 & 1.18 & -0.03 \\
\hline $\mathrm{B}$ & 1.20 & 1.23 & 0.03 & 1.15 & -0.04 & 1.20 & 0.00 & 1.15 & -0.05 & 1.18 & -0.02 & 1.18 & -0.02 \\
\hline $\mathrm{C}$ & 1.18 & 1.10 & -0.08 & 1.13 & -0.06 & 1.22 & 0.04 & 1.12 & -0.06 & 1.17 & -0.01 & 1.13 & -0.05 \\
\hline D & 1.32 & 1.28 & -0.04 & 1.40 & 0.08 & 1.31 & -0.01 & 1.27 & -0.05 & 1.26 & -0.06 & 1.27 & -0.05 \\
\hline$E$ & 1.12 & 1.23 & 0.11 & 1.17 & 0.05 & 1.18 & 0.06 & 1.12 & 0.00 & 1.16 & 0.04 & 1.07 & -0.05 \\
\hline$F$ & 1.59 & 1.36 & -0.23 & 1.42 & -0.17 & 1.44 & -0.15 & 1.36 & -0.23 & 1.40 & -0.19 & 1.55 & -0.04 \\
\hline$G$ & 1.57 & 1.16 & -0.41 & 1.29 & -0.28 & 1.40 & -0.17 & 1.46 & -0.11 & 1.46 & -0.11 & 1.51 & -0.06 \\
\hline $\mathrm{H}$ & 1.32 & 1.16 & -0.16 & 1.20 & -0.12 & 1.22 & -0.10 & 1.25 & -0.07 & 1.29 & -0.03 & 1.24 & -0.08 \\
\hline I & 1.14 & 1.15 & 0.01 & 1.13 & 0.00 & 1.13 & -0.01 & 1.14 & 0.00 & 1.16 & 0.02 & 1.16 & 0.02 \\
\hline $\mathrm{J}$ & 1.05 & 1.04 & -0.01 & 1.06 & 0.01 & 0.99 & -0.06 & 1.02 & -0.03 & 1.05 & 0.00 & 1.04 & -0.01 \\
\hline $\mathrm{K}$ & 1.00 & 0.97 & -0.03 & 0.99 & -0.01 & 0.99 & -0.01 & 1.00 & 0.00 & 1.00 & 0.00 & 0.96 & -0.04 \\
\hline L & 0.94 & 0.89 & -0.05 & 0.87 & -0.07 & 0.91 & -0.03 & 0.89 & -0.05 & 0.94 & 0.00 & 0.88 & -0.06 \\
\hline $\mid \begin{array}{c}\text { averag } \\
\mathrm{e}\end{array}$ & & & -0.08 & & -0.06 & & -0.04 & & -0.06 & & -0.04 & & -0.04 \\
\hline
\end{tabular}

Compares with the background, various cases may decrease the flood velocities and ebb velocities in channel nearby the NIIC project. Among them, the construction of $2600 \mathrm{~m}$ designed training dike will influence the effect most obviously, mean flow velocity reduced $7 \sim 8 \mathrm{~cm} / \mathrm{s}$. The construction of $+1 \mathrm{~m}$ designed training dike and the water percolation designed training dike will bring less effect with the mean velocity reduces $1 \sim 4 \mathrm{~cm} / \mathrm{s}$.

\subsubsection{Influence to flow direction in sea-route}

Various cases cause no much change in flow direction both in flood velocities and ebb velocities, the range of change is always limited in $5^{\circ}$. Various plans D F cross section rises the jet stream to the south, the angle of deflection lengthens along with the designed training dike and advances but reduces (Fig.7). The change in flow direction caused by construction of $+1 \mathrm{~m}$ designed training dike and the water percolation designed training dike was small. 


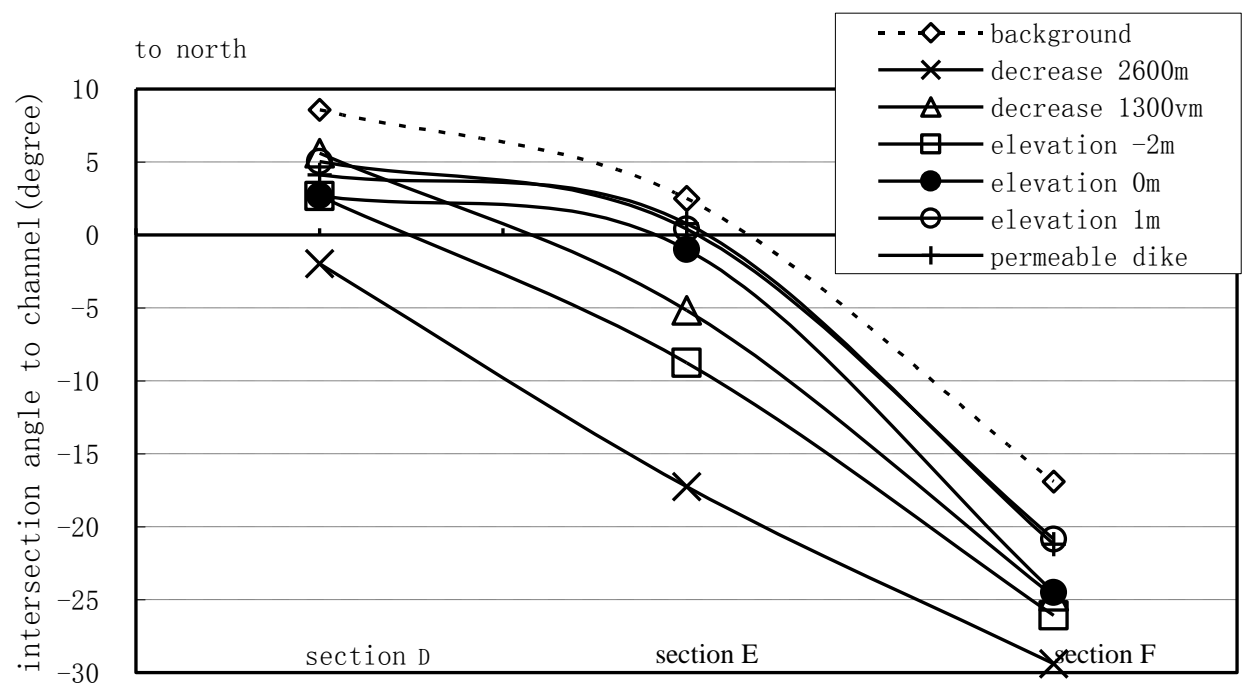

to south

Fig.7 Angle between flood flow and the channel

\subsubsection{Influence to flow structure}

In experimental schemes, the influenced circumrotating flood current structure in channel was mainly near the cross-section from 10 \# to 12 \#. The direction of flood flow slightly turned south, the angle turned decreased with the extend or advance of the training dike. Even more, the river mouth nearby revolves flows also has the change in ellipticity, the length axis ratio of revolves flows can be seen in Fig. 8 and Fig.9. Actually, The circumrotate flood current ellipse to change flatly by the circle, and the slightest change happened in the $+1 \mathrm{~m}$ designed training dike plan, following with the water percolation structure, this coincide with the effect of project.

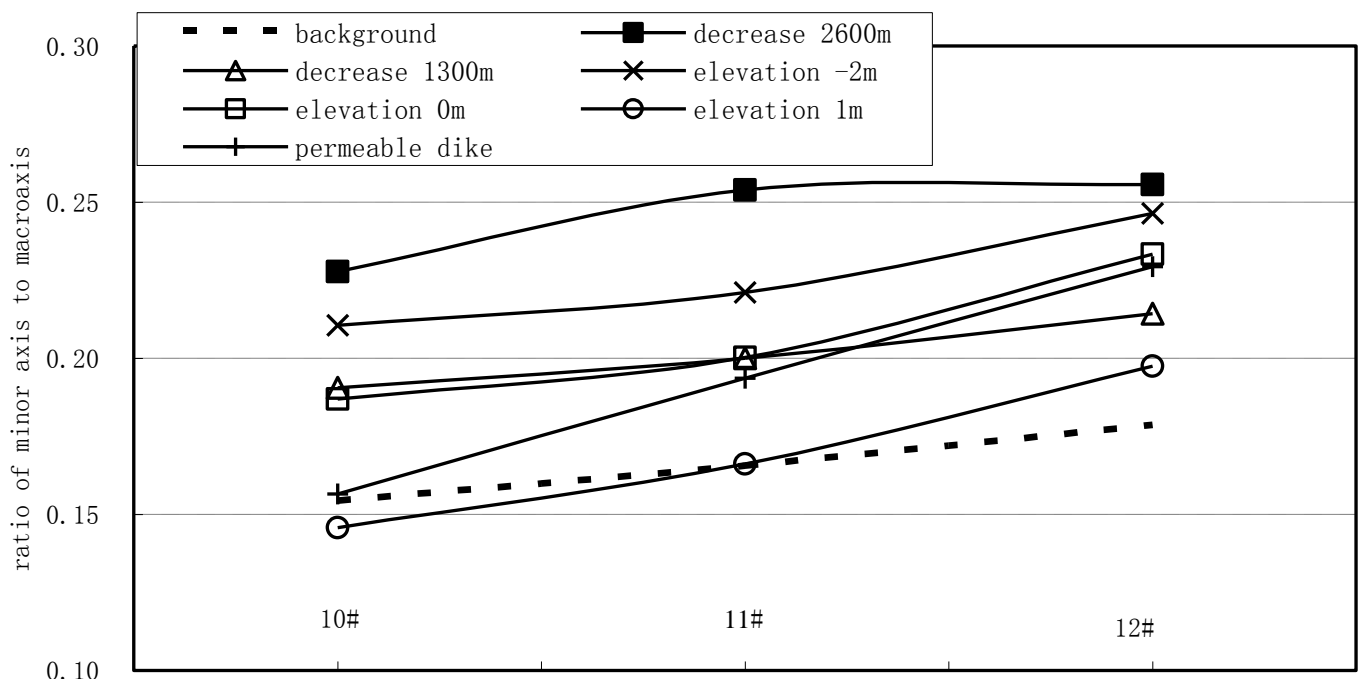

Fig.8 Ratio of minor axis to macro axis of circumrotate ebb current ellipse 


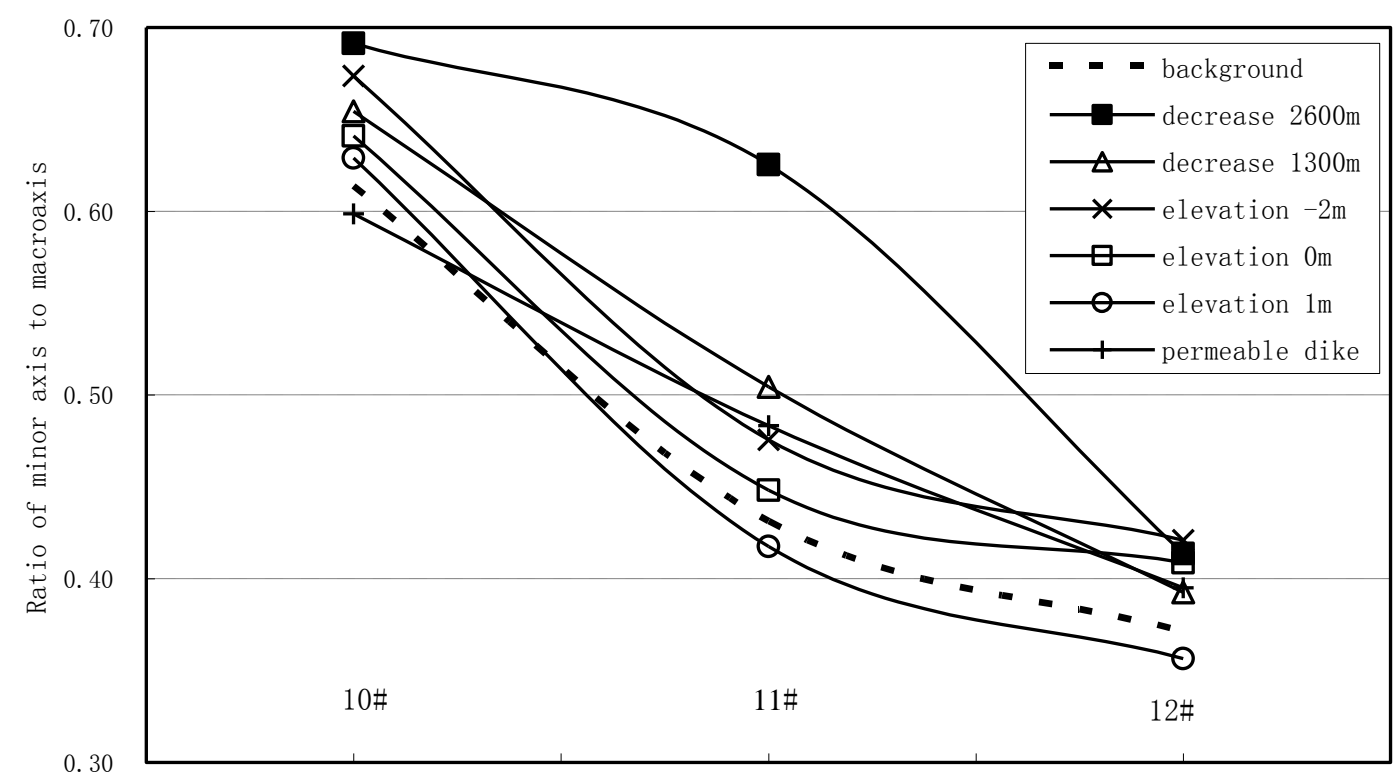

Fig.9 Ratio of minor axis to macroaxis of circumrotate flood current ellipse

\subsubsection{Influence to channel terrain}

By compare with the balanced terrain of different schemes, the channel influenced by NIIC segment was mainly limited in nearby the mouth of the northern trough. Different terrain characters caused by different schemes can be seen in table 4 .

Table 4 comparisons of terrain characters

\begin{tabular}{|c|c|c|c|c|c|c|c|}
\hline $\begin{array}{c}\text { Item } \\
\text { (isobathic) }\end{array}$ & $\begin{array}{c}\text { Backgroun } \\
\mathrm{d}\end{array}$ & $\begin{array}{c}\text { Decrease } \\
2600 \mathrm{~m}\end{array}$ & $\begin{array}{c}\text { Decrease } \\
1300 \mathrm{~m}\end{array}$ & $\begin{array}{c}\text { Dike } \\
\text { elevation } \\
-2 \mathrm{~m}\end{array}$ & $\begin{array}{c}\text { Dike } \\
\text { elevation } \\
\text { Om }\end{array}$ & $\begin{array}{c}\text { Dike } \\
\text { elevation } \\
1 \mathrm{~m}\end{array}$ & $\begin{array}{c}\text { Permeable } \\
\text { dike }\end{array}$ \\
\hline $8 \mathrm{~m}$ & $\begin{array}{c}\text { Run } \\
\text { through }\end{array}$ & $\begin{array}{c}\text { Run } \\
\text { through }\end{array}$ & $\begin{array}{c}\text { Run } \\
\text { through }\end{array}$ & $\begin{array}{c}\text { Run } \\
\text { through }\end{array}$ & $\begin{array}{c}\text { Run } \\
\text { through }\end{array}$ & $\begin{array}{c}\text { Run } \\
\text { through }\end{array}$ & $\begin{array}{c}\text { Run } \\
\text { through }\end{array}$ \\
\hline $8.5 \mathrm{~m}$ & $\begin{array}{c}\text { Run } \\
\text { through }\end{array}$ & $\begin{array}{c}\text { Interrupt } \\
3 \mathrm{~km}\end{array}$ & $\begin{array}{c}\text { Interrupt } \\
2 \mathrm{~km}\end{array}$ & $\begin{array}{c}\text { Interrupt } \\
3 \mathrm{~km}\end{array}$ & $\begin{array}{c}\text { Interrupt } \\
2 \mathrm{~km}\end{array}$ & $\begin{array}{c}\text { Run } \\
\text { through }\end{array}$ & $\begin{array}{c}\text { Interrupt } \\
0.5 \mathrm{~km}\end{array}$ \\
\hline $9 \mathrm{~m}$ & $\begin{array}{c}\text { Interrupt } \\
5 \mathrm{~km}\end{array}$ & $\begin{array}{c}\text { Interrupt } \\
8 \mathrm{~km}\end{array}$ & $\begin{array}{c}\text { Interrupt } \\
6 \mathrm{~km}\end{array}$ & $\begin{array}{c}\text { Interrupt } \\
7 \mathrm{~km}\end{array}$ & $\begin{array}{c}\text { Interrupt } \\
6 \mathrm{~km}\end{array}$ & $\begin{array}{c}\text { Interrupt } \\
6 \mathrm{~km}\end{array}$ & $\begin{array}{c}\text { Interrupt } \\
6 \mathrm{~km}\end{array}$ \\
\hline
\end{tabular}

Based on table 4, taken the background scheme as reference, the scheme with no $2600 \mathrm{~m}$ designed training dike had the worst topographical condition. The topographical condition in scheme with $+1 \mathrm{~m}$ designed training dike and the water percolation designed training dike were quite close to the background.

In conclusion, from the compare between flow velocities, flows direction, the flow structure and, terrain character and so on, the influence of construction of $2600 \mathrm{~m}$ designed training dike in NIIC segment to the effect of regulation engineering was obvious. Whether a designed training dike with the reduced elevation to $+1 \mathrm{~m}$ or the hollow block sloping faced breakwater water percolation structure was adopted seemed to be no much change to the effect of regulation engineering. 


\section{Conclusion}

In this paper we realized the partial structure simulation in river models. Taking N II C segment of the $2^{\text {nd }}$ phase project of Deep Water Channel at Yangtze Estuary as a case, the paper discussed the method of research on engineering effect of hollow block structure by combining flume experiment with physical model. It was concluded that the influence of construction of $2600 \mathrm{~m}$ designed training dike in NIIC segment to the effect of regulation engineering was obvious. In the NIIC segment, whether a designed training dike with the reduced elevation to $+1 \mathrm{~m}$ or the hollow block sloping faced breakwater water percolation structure was adopted seemed to be no much change to the effect of regulation engineering.

\section{Acknowledgements}

The study is supported by the National Natural Science Foundation of China (Grant No.50979053, Grant No.50939003) and National Key Basic Research and Development Program (No.

2010CB429002).

\section{Reference}

Han Hai-Qian, Yang Yongchu, Wang Weibiao, et al. (2002). Qiantang River estuary Wen Jia Yan riprap protection at the end of study. Journal of Sediment Research, (2) :29-34.

Huang Shen, LU Qi-Miao(1995). Estuary Dynamics. Beijing: Water Conservancy and Electric Power Press, 273 - 303.

Wu Hualin, Hu Zhifeng, Guo Wen-Hua, et al. (2003), Experimental study on optimization of the two-phase layout of Yangtze Estuary Deepwater Channel Regulation Project [M]. Estuarine and Coastal Research Institute of the Ministry of Communications.

Wu Hualin, Zhang Furan, Liu Gaofeng(2005). Experimental study on permeability of hollow block structure in Estuarine project. Water Resources and Hydropower scientific and technological progress, 25 (3) :22-31.

Wu Hualin, Zhang Furan, et al. (2006). Experimental study on engineering effect of hollow-block mound breakwater. Ocean Engineering, Vol. 24 (3), 14-22.

Xie Shileng(1996). Breakwater project (Yan Kai Editor: Port Works, Chapter IV). Beijing: China Ocean Press, 329-419.

Xie Shileng, Xie Shanwen, Wu Jin, et al. (2004) .Soft ground on the embankment slopes, hollow box. Ocean Engineering, 22 (4) :1-6.

Yang Qihuo, Wang Wenjie(2001). Strong tidal estuary Impact groin head block stability analysis. Journal of Sediment Research, (5) :14-18. 